\title{
Genetic Diversity of Local and Introduced Sweet Potato [Ipomoea batatas (L.) Lam.] Collections for Agro-morphology and Physicochemical Attributes in Ethiopia
}

\author{
Wassu Mohammed ${ }^{1 *}$, Solomon Ali $^{2}$, Beneberu Shimelis ${ }^{3}$ and Simret Burga ${ }^{1}$ \\ ${ }^{1}$ School of Plant Sciences, P.O. Box 138, Haramaya University, Dire Dawa, Ethiopia \\ ${ }^{2}$ College of Agriculture, Debre Markos University, Debre Markos, Ethiopia \\ ${ }^{3}$ School of Natural Resource Management and Environmental Sciences, P. O. Box 138, Haramaya \\ University, Dire Dawa, Ethiopia
}

\begin{abstract}
Efficient use of plant genetic diversity is a prerequisite for the development of crop varieties in meeting the challenges of food security and poverty alleviation. Understanding the variation and diversity of the genetic resources of crop species is therefore the first step to efficient utilization and genetic resource conservation. This study was therefore conducted to estimate the genetic diversity of 114 Sweet potato [Ipomoea batatas (L.) Lam] accessions obtained from Nigeria, Asia, Latin America and Local collections along with two improved varieties. Accessions were planted in 2012/13 cropping season at Haramaya University, eastern Ethiopia using Augmented design and evaluated for 17 agro-morphology and physicochemical traits. Significant differences among accessions were observed for all traits except four. Varying number of accessions obtained from Asia, Nigerian and Ethiopia performed better than improved varieties for all the traits. Heritability in broad sense and genetic advance ranged from 3.68 to 97.64 and 1.27 to $42.21 \%$, respectively. The estimated genetic distance of 6670 pairs of accessions using Euclidean distance varied from 2.04 to 11 . The Nigeria and Ethiopia collections were most distant as compared to other pairs of accessions. The dendrograms from Unweighted Pair-group Method with Arithmetic means (UPGMA) resulted in the formation of 12 clusters, which consisted accessions from different sources except Cluster III and XI, which contained accessions only from Asia. The research revealed the possibility of improving the crop through selection and the importance of further maintaining of these accessions for future improvement regardless of their geographical origin. Moreover, varied number of local collections performed better than higher performing improved variety (check) for all the traits and it was evident the presence of wide variation and genetic diversity among local and between other countries accessions. This suggested the importance of further collection, evaluation and maintaining of Sweet potato cultivars used by farmers in different regions of the country, which were introduced at different time.
\end{abstract}

Article Information

Copyright@2015 STAR Journal, Wollega University. All Rights Reserved.

Article History:

Received : 12-01-2015

Revised : 13-03-2015

Accepted : 18-03-2015

Keywords:

Accessions

Augmented design

Cluster

Euclidean distance

Genetic diversity

${ }^{*}$ Corresponding Author:

Wassu Mohammed

E-mail:

wasmoha@yahoo.com

\section{INTRODUCTION}

Sweet potato [Ipomoea batatas (L.) Lam] is originated in or near Central America and northwestern South America (Zhang et al., 2000). In Africa, it was introduced by explorers from Spain and Portugal during the $16^{\text {th }}$ century (Zhang et al., 2004, O'Brien, 1972). It is an important root crop for food security and cultivated in over 100 developing countries which ranks among the five most important food crops in over than 50 of those countries (FAOSTAT, 2012). Over $95 \%$ of the global sweet potato production is in developing countries. It is widely adapted in the tropics, sub-tropical and warm temperate regions where it is grown by smallholder farmers on marginal land with minimal inputs (Bashasha et al., 1995; Kapinga et al., 1995). Sweet potato is tolerant of a wide range of edaphic and climatic conditions and grown with limited inputs. It grows best at the $\mathrm{pH}$ of 6-7 but alkaline soils result in poor yields and very acid soils ( $\mathrm{pH}$ under 5) will not be withstood (FAO, 2006; Sigmund and Espig, 1991; FAO, 1989).

Based on the presence of large numbers of varieties, East Africa is one of the areas suggested as secondary centers of diversity (Gichuki et al., 2003). The large proportion i.e. over $70 \%$ of the Sub-Saharan Africa (SSA) region, sweet potato is produced in East and Central Africa. However, Africa produces only about $6 \%$ of the world crop, and almost all the crop is consumed directly by humans, hence the crop has a relatively large nutritional impact (Gibson et al., 2002). In Ethiopia, sweet potato has been cultivated for the last several years and 
Wassu Mohammed et al.,

over 95 percent of the crop is produced in the Southwest, Eastern and Southern parts, where it has remained for many years as one of the major subsistence crops especially in the periods of drought (Endale et al., 1992, Adhanom et al., 1985). Sweet potato ranks third after Enset [Ensete ventricosum (Wele) Cheesman] and Potato (Solanum tuberosum L.) as the most important root crops produced in the country. Sweet potato covers about 81000 hectares of land in Ethiopia with an average national yield of about $9 \mathrm{tha}^{-1}$ on farm and 25-36 $\mathrm{t} \mathrm{ha}^{-1}$ on research centers (CSA, 2011).

Several factors affect rapid improvements in productivity of the crop for specific or general environment performance but more importantly crop genotype (Aremu, et al., 2007). Plant breeders require genetically diverse material to develop improved crop varieties. The more diverse the breeding materials, the higher the probability that it would contain desirable genes and the higher probability of improving the crop for traits of interest (De Silva et al., 1995). Therefore, conservation of genetic diversity within a crop species is the basis of all variety improvement. Conservation of germplasm includes collection, proper documentation, characterization and evaluation, which the number of accessions for maintenance can be drastically reduced by eliminating duplicates (Huaman, 1992). Generally, collecting and conserving farmers' varieties is an essential activity as equal to improving and disseminating new varieties.

Cognizing the importance of germplasm collection and conservation for future crop improvement, Haramaya University maintained 114 accessions as well as the two released varieties for years which were obtained from International Centers and local collections. However, the genetic diversity of the within and between local and exotic collections was not determined. Therefore, this research was conducted with the objectives: i) to evaluate sweet potato collections for agro-morphology and physicochemical attributes and ii) to estimate the genetic diversity of within and between local and exotic collections.

\section{MATERIALS AND METHODS}

\section{Description of the Study Site}

Sweet potato accessions (116) were grown under rainfed conditions during the year 2012/2013 main cropping season at Haramaya University research field. The area receives an annual rainfall of $760 \mathrm{~mm}$ and average maximum and minimum temperatures of $23.4{ }^{\circ} \mathrm{C}$ and $8.25{ }^{\circ} \mathrm{C}$, respectively. It is situated at an altitude of 2020 m.a.s.l. and at $42^{0} 3^{\prime} \mathrm{E}$ longitudes, $9^{0} 26^{\prime} \mathrm{N}$ latitude. Analysis of the chemical and physical properties indicated that the soil has organic carbon content of $1.15 \%$, total nitrogen content of $0.11 \%$, available phosphorus content of $18.2 \mathrm{mg} \mathrm{kg} \mathrm{soil}^{-1}$, exchangeable potassium content of $0.65 \mathrm{cmol}_{\mathrm{c}} \mathrm{kg} \mathrm{soil}^{-1}$ (255 mg K kg soil $\left.{ }^{-1}\right)$, and pH of 8.0 . In addition, the percentage of sand, silt, and clay contents of the soil is reported 63,20 , and 17 , respectively (Simret, 2010).

\section{Description of Accessions}

Sweet potato accessions collected from Ethiopia (25), Introduced from Nigeria (36), Asia (52) and Cuba (1) and two improved varieties (checks) were used. The two varieties, Adu and Barkume were released for eastern Ethiopia for cultivation by Haramaya University in 2007 after fulfilling the requirements set by the National Variety
Sci. Technol. Arts Res. J., Jan-March 2015, 4(1): 09-19

Release Committee. Barkume is adapted to altitude of 1600-2000 m.a.s.I and it matured within 180- 195 days. Likewise, Adu was adapted to an altitude of 1650-2000 m.a.s.I. and matured within 150-180 days (MoARD, 2007).

Experimental Design, Planting and Field Management

The Accessions were planted using Augmented block design with 19 blocks. Each block (replication) contained 6 accessions and two checks. Each check was appearing once in each block. The checks were replicated 19 times and 114 entries were not replicated. Young portion of 30 $\mathrm{cm}$ length of the vine cuttings were planted. Hundred and $30 \mathrm{~cm}$ spacing were maintained between rows and plant, respectively. Twelve holes per plot were prepared and one vine cutting was planted in each hole of the ridge. The size of each plot was $3.3 \times 7 \mathrm{~m}\left(23.1 \mathrm{~m}^{2}\right)$. Replanting was done to substitute the dead vine after one week of planting. All plots received the recommended cultural practices uniformly.

\section{Harvesting and Sampling}

Harvesting was done after $90 \%$ of the sweet potato leaves changed in to yellowish color. From each plot, 10 plants were considered to record data including for physical and proximate analysis. In the field, the physical attributes were characterized immediately after harvest. From the total harvest, five sweet potato storage roots were randomly selected for laboratory analysis immediately after physical and yield related data were recorded. Cleaning debris and dust were done before proximate analysis. Hundred fifty-two samples were analyzed in laboratory; between those two checks were replicated 19 times the remaining 114 accessions were not replicated. The average temperature during the analysis was $25^{\circ} \mathrm{C}$ (ambient room temperature).

\section{Data Collection}

Data were collected on both plant and plot basis. The data were generated and recorded according to International Plant Genetic Resource Institute (IPGRI, 1991) to evaluate the sweet potato accessions. The physicochemical evaluation was also conducted as per the laboratory procedure, Mazumdar and Majumer (2003) and according to International Plant Genetic Resource Institute (IPGRI, 1991)

Phenological and Growth Parameters: Days to physiological maturity, number of branches per plant and vine length $(\mathrm{cm})$ were recorded from 10 plants in each plot left the two plants grown at both ends of each row as border plant.

Yield and Yield Components: Root fresh weight (g/plant), above ground fresh and dry biomass yield (g/plant), average number of storage roots per plant, average mass of storage root ( $\mathrm{g} / \mathrm{plant})$, total storage root yield $\left(\mathrm{t} \mathrm{ha}^{-1}\right)$, marketable storage root yield $\left(\mathrm{t} \mathrm{ha}^{-1}\right)$ and unmarketable storage root yield $\left(\mathrm{t} \mathrm{ha}^{-1}\right)$ were measured on plot basis.

Physicochemical Properties of Storage Roots: Physicochemical properties of storage roots were determined using the established laboratory procedures for the traits. Dry matter and moisture content (\%) was determined by oven drying procedure and calculated using the formula as proposed Zihin et al. (2011). Reducing sugar $\left(\mathrm{mg} / 100 \mathrm{gm}^{-1}\right)$ and total sugar $(\mathrm{mg} / 100$ $\mathrm{gm}^{-1}$ ) were determined with the procedures mentioned by 
Wassu Mohammed et alo,

Mazumdar and Majumer (2003). Total starch content was estimated from the total sugar percent and calculated as described by Purohit et al. (2012). pH was measured with $\mathrm{pH}$ meter from the juice extracted from five healthy sweet potato storage roots. Total soluble solids determined from extracted juice using refractometer.

\section{Statistical Analysis}

Data were subjected to analysis of variance for Augmented design using SPAD statistical software (Abhishek et al., 2010). The genetic advance that can be made also computed along with heritability, genotypic and phenotypic coefficient of variation. Descriptive statistics (range, mean, percent etc.) was used to compare differences among different groups of accessions.

The phenotypic and genotypic variance and coefficient of variation were estimated according to the methods suggested by Burton and Devane (1953). Heritability $\left(\mathrm{H}_{2}\right)$ in broad sense was computed using the formula adopted by Allard (1960) and Falconer (1990) as: $\mathrm{H}_{2}=\left[\sigma^{2} \mathrm{~g} / \sigma^{2} \mathrm{p}\right] \mathrm{x}$ 100 , where, $\sigma^{2} g=$ genotypic variance, $\sigma^{2} p=$ phenotypic variance and $\sigma^{2} e=$ error variance. Genetic advance/gain as percent of the mean (GA) for each trait was computed using the formula adopted by Johnson et al., (1955) and Allard (1960) as: $\mathrm{GA}=(\mathrm{k})(\sigma \mathrm{p})^{\star}\left(\mathrm{H}_{2}\right)$, and $\mathrm{GA}$ (as \% of the mean $)=\left[\frac{G A)}{X}\right] x 100$, where, $\mathrm{k}=$ selection differential $(\mathrm{k}=2.06$ at $5 \%$ selection intensity), $\sigma p=$ phenotypic standard deviation, $\mathrm{H}_{2}=$ heritability in broad sense and $\mathrm{x}=$ grand mean.
Sci. Technol. Arts Res. J., Jan-March 2015, 4(1): 09-19

Euclidean distance (ED) was computed from the 17 agro-morphology and physicochemical traits of 116 sweet potato accessions after standardization (subtracting the mean value and dividing it by the standard deviation) as:

$$
\mathrm{EDjk}=\sqrt{\sum_{i=1}^{n}(X i j-X i k)^{2}}
$$

(Sneath and Sokal, 1973),

where EDjk = distance between accessions $\mathrm{j}$ and $\mathrm{k}$; $\mathrm{xij}$ and $\mathrm{xik}=$ agro-morphology and physicochemical trait values of the $i^{\text {th }}$ trait for accession $j$ and $k$, respectively; and $\mathrm{n}=$ number of agro-morphology and physicochemical traits used to calculate the distance. The distance matrix from agro-morphology and physicochemical traits was used to construct dendrograms based on the Unweighted Pair-group Method with Arithmetic means (UPGMA) and the results were presented in the form of dendrogram.

\section{RESULTS}

\section{Analysis of Variance and Mean Performance of Accessions}

The analysis of variance computed for 17 traits revealed the presence of significant differences among accessions for all traits except number of branches per plant, vine length, above ground fresh and dry biomass yield (Table 1). Significant difference between improved varieties (checks) was also observed for 10 out of 17 traits.

Table 1: Mean squares from analysis of variance, heritability and genetic advance for 17 traits of 116 sweet potato accessions

\begin{tabular}{|c|c|c|c|c|c|c|c|c|}
\hline Trait & $\begin{array}{c}\text { Block } \\
(18)\end{array}$ & $\begin{array}{c}\text { Checks } \\
\text { (1) }\end{array}$ & $\begin{array}{c}\text { Accession } \\
(115)\end{array}$ & $\begin{array}{l}\text { Error } \\
(18)\end{array}$ & GCV & PCV & $\begin{array}{l}\mathrm{H}_{2} \\
\% \\
\%\end{array}$ & $\begin{array}{c}\text { GAM } \\
5 \%\end{array}$ \\
\hline Days to physiological maturity & 2 & $351.4^{\star *}$ & $380.71^{\star \star}$ & 2.58 & 2.73 & 2.89 & 89.06 & 5.31 \\
\hline Number of branches per plant & 2.32 & $4^{\mathrm{ns}}$ & $4.81^{\mathrm{ns}}$ & 2.85 & 4.04 & 21.05 & 3.68 & 1.60 \\
\hline Vine length $(\mathrm{cm})$ & 336.38 & $151.6^{\mathrm{ns}}$ & $436.66^{\mathrm{ns}}$ & 231.39 & 4.98 & 22.96 & 4.70 & 2.22 \\
\hline Root fresh weight (g/plant) & 55646.28 & $351318.6^{* *}$ & $66130.4^{*}$ & 26267.22 & 14.59 & 52.31 & 7.78 & 8.38 \\
\hline Above ground fresh biomass yield (g/plant) & 161301.68 & $221885.81^{*}$ & $106538.44^{\mathrm{ns}}$ & 56312.68 & 2.83 & 13.02 & 4.72 & 1.27 \\
\hline Above ground dry biomass yield (g/plant) & 161301.68 & $212975.84^{*}$ & $106538.44^{\text {ns }}$ & 56312.68 & 5.56 & 25.61 & 4.72 & 2.49 \\
\hline Average number of storage roots per plant & 5.35 & 2.88ns & $17.5^{\star}$ & 3.96 & 13.65 & 34.17 & 15.96 & 11.24 \\
\hline Average mass of storage roots $(\mathrm{g})$ & 2158.2 & $21.9 n s$ & $6952.7^{*}$ & 2278.8 & 11.50 & 35.96 & 10.23 & 7.58 \\
\hline Total storage root yield $\left(\mathrm{t} \mathrm{ha}^{-1}\right)$ & 20.02 & $53.8^{\mathrm{ns}}$ & $24.79^{*}$ & 9.59 & 8.55 & 30.07 & 8.09 & 5.01 \\
\hline Marketable storage root yield $\left(\mathrm{t} \mathrm{ha}^{-1}\right)$ & 10.4 & $30.7^{*}$ & $15.15^{*}$ & 5.79 & 10.28 & 35.80 & 8.24 & 6.08 \\
\hline Unmarketable storage root yield $\left(\mathrm{t} \mathrm{ha}^{-1}\right)$ & 8.84 & $1.38^{\mathrm{ns}}$ & $14.67^{*}$ & 3.67 & 20.92 & 55.38 & 14.27 & 16.29 \\
\hline Dry matter content (\%) & 13.01 & $21.61^{*}$ & $23.1^{*}$ & 6.16 & 4.08 & 11.21 & 13.25 & 3.06 \\
\hline Reducing sugar(mg/100 $\left.\mathrm{gm}^{-1}\right)$ & 0.42 & $2.6^{* *}$ & $2.18^{* *}$ & 0.23 & 5.41 & 9.57 & 32.02 & 6.31 \\
\hline Total Sugar $\left(\mathrm{mg} / 100 \mathrm{gm}^{-1}\right)$ & 1.29 & $5.7^{* \star}$ & $2.72^{* *}$ & 0.55 & 2.63 & 6.20 & 17.98 & 2.30 \\
\hline Total starch content $\left(\mathrm{mg} / 100 \mathrm{~g}^{-1}\right)$ & 1.16 & $11.9^{* *}$ & $3.55^{* *}$ & 0.49 & 3.29 & 6.48 & 25.76 & 3.44 \\
\hline $\mathrm{pH}$ & 0.04 & $0.05^{\mathrm{ns}}$ & $29.79^{* *}$ & 0.04 & 20.73 & 20.98 & 97.64 & 42.21 \\
\hline Total soluble solid (TSS) & 1.16 & $5.6^{* *}$ & $3.55^{\star *}$ & 0.9 & 3.08 & 8.22 & 14.06 & 2.38 \\
\hline
\end{tabular}

${ }^{*},{ }^{* *}$ and ns, significant at $\mathrm{P}<0.05, \mathrm{P}<0.01$ and non- significant, respectively. $\mathrm{GCV}=$ genotypic coefficient of variation, $\mathrm{PCV}=$ phenotypic coefficient of variation, $\mathrm{H}_{2} \%=$ heritability in broad sense in percent and GAM $(5 \%)=$ genetic advance as percent of the mean

The mean performance of each group of accessions is presented in Table 2 and Table 3 . The accessions had a wide range of mean values for each trait. The improved varieties used as check had highest mean values for seven traits viz. days to physiological maturity, storage root fresh weight gram per plant, average mass of storage root gram per plant, total storage root yield ton per hectare, marketable storage root yield ton per hectare, unmarketable storage root yield ton per hectare and dry matter content in percent. Accessions introduced from Asia had highest overall mean for four traits (number of branches per plant, total sugar content, total starch content in percent and $\mathrm{pH}$ ) and one accession introduced from Cuba had highest mean values for four traits (above ground fresh and dry biomass yield gram per plant, total soluble solid and average number of storage roots per plant). Accessions introduced from Nigeria and local collections had only highest overall mean values for 
Wassu Mohammed et alo,

reducing sugar content and vine length in centimeter, respectively. On the other hand, the accession introduced from Cuba mean values for seven traits, while the improved varieties for four traits and accession introduced from Nigeria and local collections each for three traits had lowest overall mean values. Considering individual
Sci. Technol. Arts Res. J., Jan-March 2015, 4(1): 09-19

accessions, Asia and Nigerian origin exhibited the highest mean values for eight and five traits, respectively. Individual accessions from local collections also recorded the highest mean values for four traits while none of the checks and accession from Cuba registered highest mean value for any of the traits.

Table 2: Minimum, maximum and mean performance of 113 exotic and local collections of sweet potato

\begin{tabular}{|c|c|c|c|c|c|c|c|c|c|c|c|c|}
\hline \multirow{2}{*}{ Trait } & \multicolumn{4}{|c|}{ Introduction from Nigeria } & \multicolumn{4}{|c|}{ Introduction from Asia } & \multicolumn{4}{|c|}{ Local collections } \\
\hline & Min & Max & Mean & SD & Min & Max & Mean & SD & Min & Max & Mean & SD \\
\hline DTPM & 120.342 & 190.342 & 162.814 & 17.849 & 122.842 & 197.342 & 170.092 & 14.344 & 111.342 & 198.842 & 167.682 & 22.254 \\
\hline NBP & 2.947 & 12.447 & 7.753 & 2.349 & 3.447 & 20.447 & 8.466 & 2.595 & 1.447 & 11.447 & 8.247 & 2.345 \\
\hline $\mathrm{VL}(\mathrm{cm})$ & 7.112 & 98.612 & 52.316 & 23.143 & 23.737 & 122.862 & 73.777 & 24.645 & 40.862 & 138.862 & 79.612 & 21.553 \\
\hline SRFW(g) & 90.54 & 854.26 & 330.251 & 167.700 & 74.94 & 662.65 & 330.593 & 138.036 & 88.59 & 799.9 & 282.019 & 168.108 \\
\hline AGFB & 615 & 3615 & 1776.944 & 661.129 & 265 & 5060 & 1703.462 & 974.623 & 765 & 4865 & 2347.400 & 930.327 \\
\hline AGDB & 225 & 1605 & 852.778 & 339.381 & 210 & 2016 & 910.462 & 412.012 & 510 & 2145 & 1162.880 & 390.847 \\
\hline ANSR/p & 2.00 & 9.00 & 4.944 & 1.603 & 4.00 & 11.00 & 7.212 & 1.564 & 4.00 & 10.00 & 6.60 & 1.384 \\
\hline AMSR/p & 18 & 318 & 155.500 & 81.394 & 18 & 268 & 133.654 & 61.780 & 68 & 218 & 132.00 & 62.115 \\
\hline TSRYt ha ${ }^{-1}$ & 2.311 & 28.461 & 10.992 & 5.613 & 2.511 & 22.061 & 11.024 & 4.632 & 2.261 & 26.661 & 9.36 & 5.657 \\
\hline MSRYt ha ${ }^{-1}$ & 0.512 & 22.088 & 8.219 & 4.798 & 2.012 & 14.352 & 6.739 & 3.243 & 1.592 & 13.852 & 5.49 & 3.514 \\
\hline USRYt ha ${ }^{-1}$ & 0.076 & 6.976 & 2.790 & 2.061 & 0.001 & 10.246 & 4.281 & 2.604 & 0.161 & 13.631 & 3.91 & 3.142 \\
\hline DMC (\%) & 13.275 & 33.81 & 22.070 & 4.497 & 17.11 & 40.215 & 25.256 & 5.218 & 13.715 & 35.715 & 22.99 & 5.601 \\
\hline RS & 3.901 & 9.641 & 6.388 & 1.571 & 3.316 & 10.331 & 6.128 & 1.794 & 2.576 & 9.211 & 5.56 & 1.690 \\
\hline TS & 9.533 & 16.443 & 12.621 & 1.811 & 10.723 & 17.258 & 13.737 & 1.812 & 10.503 & 16.423 & 13.05 & 1.711 \\
\hline TSC (\%) & 9.052 & 15.617 & 11.971 & 1.726 & 10.187 & 16.402 & 13.050 & 1.722 & 9.977 & 15.597 & 12.39 & 1.624 \\
\hline $\mathrm{pH}$ & 5.044 & 6.989 & 6.134 & 0.314 & 5.834 & 7.264 & 6.252 & 0.291 & 5.729 & 6.949 & 6.20 & 0.272 \\
\hline TSS & 9.132 & 17.132 & 12.951 & 2.168 & 7.132 & 15.382 & 11.863 & 1.630 & 8.132 & 15.632 & 13.02 & 1.702 \\
\hline
\end{tabular}

per plant, AGFB = storage roots per plant, $A M S R / p=$ average mass of storage root gram per plant, TSRY $t h^{-1}=$ total storage root yield ton per hectare, $\mathrm{MSRY}^{\mathrm{t}}$ ha ${ }^{-1}=$ marketable storage root yield ton per hectare, USRY $\mathrm{t} \mathrm{ha}^{-1}=$ unmarketable storage root yield ton per hectare, DMC $(\%)=\mathrm{dry}$ matter content in percent, RS= reducing sugar content, TS= total sugar content, TSC $(\%)=$ total starch content in percent and TSS $=$ total soluble solids

Table 3: Mean performance of improved sweet potato varieties, one accession from Cuba and overall accessions mean performance

\begin{tabular}{|c|c|c|c|c|c|c|c|c|}
\hline \multirow[b]{2}{*}{ Trait } & \multirow{2}{*}{ Adu } & \multirow{2}{*}{ Berkume } & \multirow{2}{*}{$\begin{array}{l}\text { Mean released } \\
\text { varieties }\end{array}$} & \multirow{2}{*}{ Cuba 1} & \multicolumn{4}{|c|}{ Overall } \\
\hline & & & & & Min & Max & Mean & SD \\
\hline DTPM & 186.737 & 191.947 & 189.342 & 188.842 & 111.342 & 198.842 & 167.808 & 17.713 \\
\hline NBP & 8.684 & 8.211 & 8.4475 & 5.447 & 1.447 & 20.447 & 8.171 & 2.445 \\
\hline VL $(\mathrm{cm})$ & 61.487 & 55.487 & 58.487 & 46.862 & 7.112 & 138.862 & 67.879 & 25.619 \\
\hline $\operatorname{SRFW}(\mathrm{g})$ & 536.32 & 435.87 & 486.095 & 318.69 & 74.94 & 854.26 & 322.597 & 154.341 \\
\hline AGFB & 1267 & 1463 & 1365 & 2615 & 265 & 5060 & 1867.069 & 899.516 \\
\hline AGDB & 728 & 843 & 785.5 & 1450 & 210 & 2145 & 949.457 & 398.041 \\
\hline ANSR/p & 4.00 & 7.00 & 5.50 & 8.00 & 2.00 & 11.00 & 6.353 & 1.819 \\
\hline $\mathrm{AMSR} / \mathrm{p}$ & 153 & 184 & 168.5 & 68 & 18 & 318 & 140.112 & 68.446 \\
\hline TSRYt ha ${ }^{-1}$ & 17.879 & 14.542 & 16.2105 & 10.661 & 2.261 & 28.461 & 10.742 & 5.156 \\
\hline MSRYt ha $^{-1}$ & 13.039 & 10.505 & 11.772 & 6.792 & 0.512 & 22.088 & 7.017 & 3.958 \\
\hline USRYt ha ${ }^{-1}$ & 4.838 & 4.024 & 4.431 & 3.831 & 0.001 & 13.631 & 3.736 & 2.606 \\
\hline DMC (\%) & 28.871 & 27.98 & 28.4255 & 18.385 & 13.275 & 40.215 & 23.776 & 5.238 \\
\hline RS & 6.881 & 5.811 & 6.346 & 4.981 & 2.576 & 10.331 & 6.080 & 1.697 \\
\hline TS & 14.551 & 12.655 & 13.603 & 10.478 & 9.533 & 17.258 & 13.213 & 1.841 \\
\hline TSC (\%) & 13.822 & 12.023 & 12.9225 & 9.952 & 9.052 & 16.402 & 12.546 & 1.752 \\
\hline $\mathrm{pH}$ & 6.086 & 6.031 & 6.0585 & 6.139 & 5.044 & 7.264 & 6.200 & 0.293 \\
\hline TSS & 10.632 & 11.632 & 11.132 & 13.382 & 7.132 & 17.132 & 12.451 & 1.887 \\
\hline
\end{tabular}

Min=minimum value, Max=maximum value, $\mathrm{SD}=$ standard deviation, $\mathrm{DTPM}=$ days to physiological maturity, $\mathrm{NBP}=$ number of branches per plant, $\mathrm{VL}(\mathrm{cm})=$ vine length in centimeter, $\operatorname{SRFW}(\mathrm{g})=$ storage root fresh weight gram per plant, AGFB= above ground fresh biomass yield gram per plant, $A G D B=$ above ground dry biomass gram per plant, ANSR/p= average number of storage roots per plant, $\mathrm{AMSR} / \mathrm{p}=$ average mass of storage root gram per plant, $\mathrm{TSRY} \mathrm{t} \mathrm{ha}^{-1}=$ total storage root yield ton per hectare, $\mathrm{MSRY}_{\mathrm{t}}$ ha ${ }^{-1}=\mathrm{marketable}$ storage root yield ton per hectare, USRY $\mathrm{t} \mathrm{ha}^{-1}=$ unmarketable storage root yield ton per hectare, DMC $(\%)=$ dry matter content in percent, RS= reducing sugar content, TS= total sugar content, TSC $(\%)=$ total starch content in percent and TSS $=$ total soluble solids.

The variation among accessions was too large where the differences ranged from $17.56 \%(\mathrm{pH})$ to $98.82 \%$ (unmarketable storage root yield) between the highest and lowest performing accessions. Moreover, the total and marketable storage-root yield difference ranged from null to 91.52 and $88.51 \%$, respectively. If earliness is becoming breeding objective, it was possible to find up to
88 days earlier than late maturing ones. As compared to the best performing check, the new entries had advantages over improved varieties (checks) for all the traits which ranged from 5.87 (marketable storage root yield) to $69.93 \%$ (aboveground fresh biomass). Accessions were as early as up to 74 days and late up to seven days as compared to the early and late maturing 


\section{Wassu Mohammed et al.,}

improved varieties (checks), respectively. Total storage root yield, dry matter and starch content advantages over high performing check were up to $32.94 \%, 19.16$ and $11.38 \%$, respectively.

\section{Heritability, Genetic advance and Coefficient of Variations}

The highest heritability in broad sense and genetic advance values of 97.64 and $42.21 \%$, respectively, were computed for $\mathrm{pH}$. On the other hand, the lowest heritability and genetic advance values of 3.68 and $1.27 \%$ were computed for number of branches per plant and above ground fresh biomass yield (g/plant), respectively. Genotypic (GCV) and phenotypic coefficient of variations (PCV) ranged from 2.73 to $20.92 \%$ and 2.89 to $55.38 \%$, respectively. The lowest and highest values were recorded for days to physiological maturity and unmarketable storage root yield $\left(\mathrm{t} \mathrm{ha}^{-1}\right)$, respectively, for both GCV and PCV (Table 1). The calculated phenotypic coefficient of variation was higher than genotypic coefficient of variation values for all traits.

\section{Genetic Diversity}

Genetic diversity was estimated using Euclidean distance and the genetic distance of 6670 pairs of
Sci. Technol. Arts Res. J., Jan-March 2015, 4(1): 09-19

accessions was computed. However, it was not possible to present genetic distances of all pairs of accessions and only the summary of results is presented (Table 4). The estimated genetic distance varied from 2.04 to 11 with mean genetic distance of 5.67 and standard deviation of 1.37. The large proportion of pairs of accessions (4636) had genetic distances of 4.3 to 7.04 while 1040 and 1010 pairs of accessions had $<4.3$ and $>7.04$ genetic distances, respectively. Barkume improved variety (check) had relatively lowest genetic distances with 36 accessions introduced from Nigerian which ranged from 2.37 to 6.4 with lowest mean and standard deviation of 4.8 and 0.9 . The other improved variety (Adu) used as a check was relatively more distant with 25 local collections with genetic distance between 3.58 to 7.9 , mean and standard deviation of 5.94 and 1.24, respectively. Among collections of different origin, the Nigeria and local collections were most distant which exhibited between 2.59 to 11.0 with 5.59 mean genetic distance and standard deviation of 1.47 . The accessions introduced from Nigeria were less distant with the accession introduced from Cuba. The Asian accessions among them were not as distant as Nigeria and local collections. The two improved varieties (checks) were close each other with 2.73 genetic distance.

Table 4: Mean and range of genetic distances and number of accessions with lowest, moderate and highest genetic distances on the each group of accessions

\begin{tabular}{lcccccc}
\hline Group of accession & Range & Mean & SD & $<\mathbf{4 . 3}$ & $\mathbf{4 . 3}$ to $\mathbf{7 . 0 4}$ & $\mathbf{> 7 . 0 4}$ \\
\hline All accession & $2.04-11$ & 5.67 & 1.37 & 1024 & 4636 & 1010 \\
Barkume to Nigeria & $2.37-6.4$ & 4.8 & 0.9 & 9 & 27 & 0 \\
Barkume to Local & $3.12-7.2$ & 5.04 & 1.12 & 7 & 17 & 1 \\
Barkume to Asia & $3.06-7.0$ & 4.53 & 0.93 & 25 & 27 & 0 \\
Adu to Nigeria & $3.71-7.4$ & 5.41 & 0.99 & 6 & 28 & 2 \\
Adu to Local & $3.58-7.9$ & 5.94 & 1.24 & 3 & 17 & 5 \\
Adu to Asia & $3.11-7.33$ & 5.18 & 1.07 & 11 & 38 & 3 \\
Nigeria to Nigeria & $2.04-10.5$ & 5.59 & 1.47 & 125 & 406 & 99 \\
Nigeria to Local & $2.59-11.0$ & 5.59 & 1.47 & 88 & 663 & 149 \\
Nigeria to Cuba & $2.96-9.39$ & 5.45 & 1.22 & 6 & 27 & 3 \\
Nigeria to Asia & $2.54-10.5$ & 5.87 & 1.35 & 136 & 1398 & 338 \\
Local to Local & $2.6-10.9$ & 5.56 & 1.61 & 72 & 186 & 42 \\
Local to Cuba & $3.64-8.32$ & 5.16 & 1.03 & 5 & 18 & 2 \\
Local to Asia & $2.3-10.4$ & 5.66 & 1.35 & 215 & 872 & 213 \\
Asia to Asia & $2.27-10$ & 5.44 & 1.24 & 163 & 1023 & 140 \\
Asia to Cuba & $3.54-8.12$ & 5.59 & 1.04 & 4 & 45 & 3 \\
\hline
\end{tabular}

The dendrograms from Unweighted Pair-group Method with Arithmetic means (UPGMA) cluster analysis based on Euclidean distance (ED) matrixes are presented in Figure 1. Clustering based on ED cut at 4.5 space (Above the mean distance minus the standard deviation) resulted in the formation of 12 cluster of which one (Cluster XI) was comprised a single sweet potato accession obtained from Asia. The other clusters comprised 3 (Cluster VI and $\mathrm{X}$ ) to 33 (Cluster $\mathrm{V}$ ) accessions. Cluster $\mathrm{V}$ that contained many accessions was sub-grouped in to I, II, III and IV with $9,8,6$ and 10 accessions, respectively. This cluster consisted of accessions from all sources where many accessions were from Asia and Nigeria. Cluster IV subdivided in two sub-groups each with 9 accessions introduced from Nigeria and Asia. Cluster II sub-grouped to three which the two subgroups each with five and the third with four accessions of all from Asia and Nigeria except one from local collection. Cluster IX divided in to two subgroups i.e. one with six and the other three accessions of which 4, 3 and 2 were from Asia, local and Nigeria, respectively (Table 5 ). The two checks were grouped under Cluster I, while accessions introduced from Asia distributed in all clusters excerpt Cluster XII. Accessions from Nigeria also distributed in all clusters except III, VIII and XI. The local collections were distributed in all clusters except III, IV and XI of which 11 out of 25 were grouped under Cluster V.

The mean distance was calculated for accessions in each cluster and each cluster accessions with accessions in other clusters. Accessions mean distances with other accessions within cluster and between accessions in other clusters with extreme mean distances sorted in each cluster are presented in Table 6. Cluster VI had the lowest mean genetic distance (3.69) and standard deviation (0.28) with accessions, which had as low as 3.52 and maximum of 4 genetic distances within a cluster. Cluster $V$ showed lowest mean distance of 5.1 with other clusters. Cluster XII had the highest mean distance of 5.85 and 7.89 within and between clusters, respectively. Accessions in this cluster also exhibited highest mean distance within and between clusters members. 


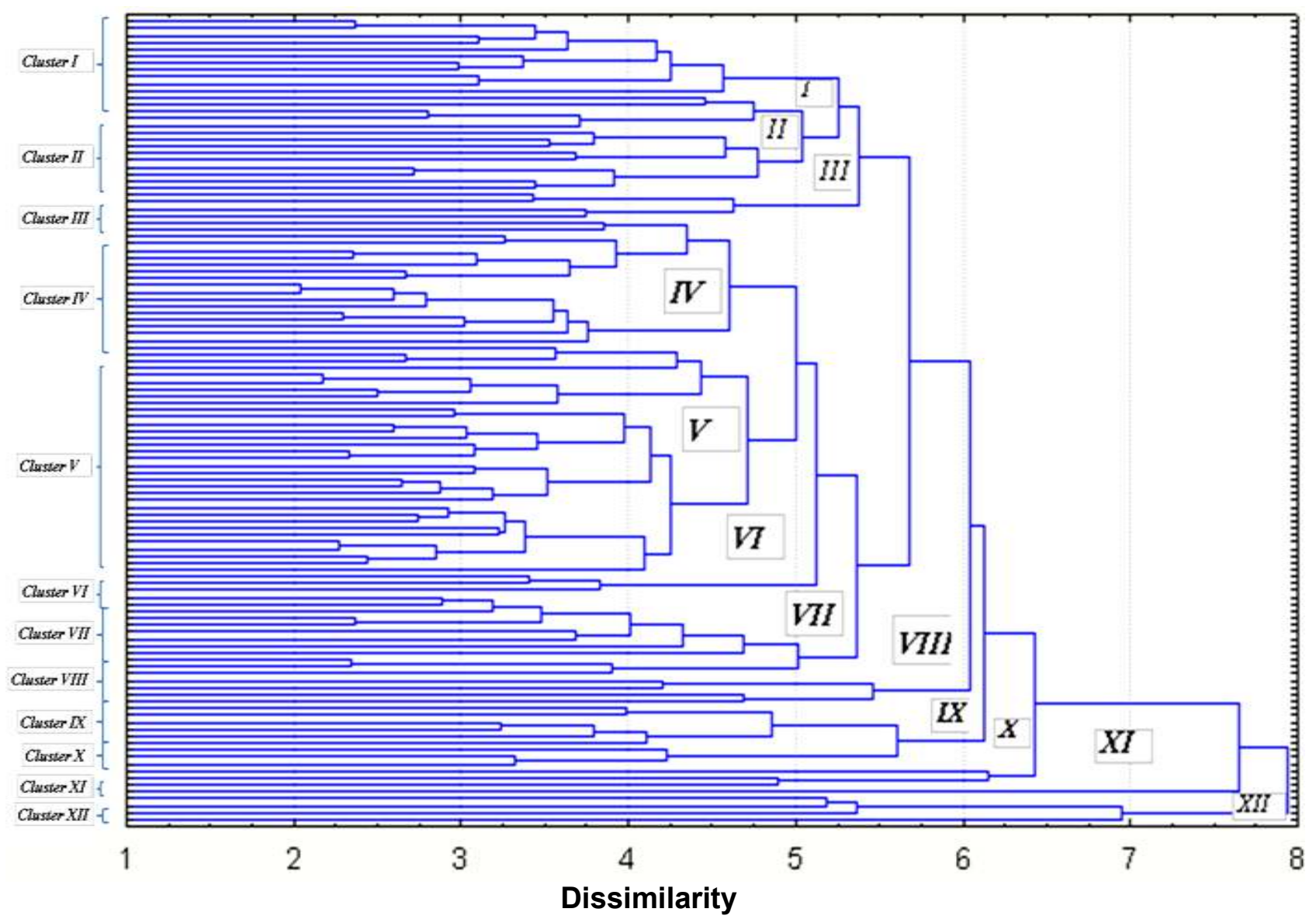

Figure 1: Dendogram generated based on UPGMA clustering method depicting genetic relationships among 116 sweet potato accessions based on 17 traits

Table 5: List of accessions in 12 cluster groups and sub-groups with designation number

\begin{tabular}{|c|c|c|c|c|c|c|c|c|c|c|c|}
\hline Cluster & Accession & No & Cluster & Accession & No & Cluster & Accession & No & Cluster & Accession & No \\
\hline \multirow[t]{11}{*}{ C-I (11) } & Barkume & 1 & C-IV (18) & Tis-8250-9 & 30 & C-V & Tis-8441-4 & 59 & \multirow[t]{8}{*}{ C-VII } & Tis-8250-4 & 88 \\
\hline & Tis-70357-5 & 2 & \multirow[t]{8}{*}{ Sub G I=9 } & CN-1775-3 & 31 & \multirow[t]{5}{*}{ Sub G II } & Koka-26 & 60 & & Tis-9465-1 & 89 \\
\hline & CN-2066-2 & 3 & & Tis-8250-1 & 32 & & Wondogenet & 61 & & Tis-9465-8 & 90 \\
\hline & CN-2054-2 & 4 & & $\mathrm{CN}-2065-18$ & 33 & & Becale type-3 & 62 & & Tis-9065-1 & 91 \\
\hline & Tis-9465-8 & 5 & & Tis-9465-2 & 34 & & Guracha & 63 & & Becale-B & 92 \\
\hline & Adu & 6 & & Tis-80/043-3 & 35 & & $\mathrm{CN}-1754-3$ & 64 & & Koka-14 & 93 \\
\hline & Arbaminch & 7 & & $\mathrm{CN}-1754-12$ & 36 & \multirow[t]{6}{*}{ Sub G III=6 } & Tis-70357-2 & 65 & & $\mathrm{CN}-2065-12$ & 94 \\
\hline & CN-1753-5 & 8 & & CN-2059-9 & 37 & & Alemaya-local-2 & 66 & & Korojo-2 & 95 \\
\hline & Becale & 9 & & $\mathrm{CN}-2065-16$ & 38 & & Alemaya-local-3 & 67 & \multirow[t]{4}{*}{ C-VIII (4) } & Cemsa & 96 \\
\hline & CN-1775-4 & 10 & \multirow[t]{9}{*}{ Sub G $\|=9$} & Tis-8250-8A & 39 & & Becale-type-2 & 68 & & CN-2065-7 & 97 \\
\hline & $\mathrm{CN}-1752-9$ & 11 & & Tis- $9465-10$ & 40 & & Lesh type-1 & 69 & & CN-2065-8 & 98 \\
\hline C-II (14) & Tis-8441-11 & 12 & & CN-1753-15 & 41 & & Korojo-1 & 70 & & $\mathrm{CN}-2065-6$ & 99 \\
\hline \multirow[t]{4}{*}{ Sub-G I=5 } & Tis-9065-5 & 13 & & CN-2054-5 & 42 & \multirow[t]{10}{*}{ Sub G IV $=10$} & Tis-8250-2 & 71 & \multirow{6}{*}{$\begin{array}{l}\text { C-IX (9) } \\
\text { sub G } 1=6\end{array}$} & Tis-9068-8 & 100 \\
\hline & $\mathrm{CN}-1752-8$ & 14 & & $\mathrm{CN}-1753-7$ & 43 & & Becale-1B & 72 & & Tis-9068-2 & 101 \\
\hline & $\mathrm{CN}-1752-15$ & 15 & & CN-1753-8 & 44 & & CN-1753-20 & 73 & & Koka-9 & 102 \\
\hline & $\mathrm{CN}-2059-8$ & 16 & & CN-1754-6 & 45 & & Bacariso & 74 & & CN-1752-6 & 103 \\
\hline \multirow[t]{5}{*}{ Sub $G \|=5$} & Tis-8441-3 & 17 & & $\mathrm{CN}-1754-5$ & 46 & & $\mathrm{CN}-2059-1$ & 75 & & Awassa-83 & 104 \\
\hline & CN-2059-4 & 18 & & $\mathrm{CN}-1753-1$ & 47 & & CN-2065-5B & 76 & & CN-2065-11 & 105 \\
\hline & CN-1753-16 & 19 & \multirow{9}{*}{$\begin{array}{l}\text { C-V (33) } \\
\text { Sub G I=9 }\end{array}$} & Tis-9068-6 & 48 & & CN-1752-5 & 77 & \multirow[t]{3}{*}{ sub G I1=3 } & Nefissie & 106 \\
\hline & Becale type-1 & 20 & & CN-1754-9 & 49 & & CN-2066-4 & 78 & & CN-2065-5A & 107 \\
\hline & CN-2059-6 & 21 & & $\mathrm{CN}-1752-14$ & 50 & & $\mathrm{CN}-1754-11$ & 79 & & $\mathrm{CN}-2065-10$ & 108 \\
\hline \multirow[t]{4}{*}{ Sub G $\| I=4$} & CN-1753-12 & 22 & & Tis-9468-7 & 51 & & CN-2054-1 & 80 & \multirow[t]{3}{*}{ C-X (3) } & Tis-82/0602-1A & 109 \\
\hline & $\mathrm{CN}-1753-13$ & 23 & & Tis-80/043-2 & 52 & \multirow[t]{3}{*}{ C-VI (3) } & Tis-82/0602-1B & 81 & & Korojo & 110 \\
\hline & CN-2054-7 & 24 & & Tis-82/062-11 & 53 & & Abadiro & 82 & & $\mathrm{CN}-2065-15$ & 111 \\
\hline & CN-1753-19 & 25 & & Tis-8250-7 & 54 & & CN-2065-1 & 83 & C-XI (1) & $\mathrm{CN}-2059-7$ & 112 \\
\hline \multirow[t]{4}{*}{ C-III (4) } & $\mathrm{CN}-1753-11$ & 26 & & Tis-9465-9 & 55 & \multirow[t]{4}{*}{ C-VII (12) } & Tis-82/0602-2 & 84 & \multirow[t]{4}{*}{ C-XII (4) } & Tis-82/0602-12 & 113 \\
\hline & $\mathrm{CN}-1753-18$ & 27 & & Tis-9068-3 & 56 & & Tis-80/043-1 & 85 & & Tis-70357-7 & 114 \\
\hline & $\mathrm{CN}-1753-14$ & 28 & Sub G $\|=8$ & Tis-8441-1 & 57 & & Tis-82/0602-6 & 86 & & Tis-9465-7 & 115 \\
\hline & $\mathrm{CN}-1753-17$ & 29 & & Cuba-1 & 58 & & Tis-70357-4 & 87 & & Koka-12 & 116 \\
\hline
\end{tabular}


Table 6: Minimum, maximum and mean genetic distances (GD) of within and between 12 clusters

\begin{tabular}{|c|c|c|c|c|c|c|c|c|c|c|}
\hline \multirow[b]{2}{*}{ Cluster } & \multicolumn{6}{|c|}{ Within Cluster } & \multicolumn{4}{|c|}{ With other clusters } \\
\hline & Mean & SD & $\begin{array}{c}\text { Lowest } \\
\text { mean }\end{array}$ & $\begin{array}{c}\text { Highest } \\
\text { mean }\end{array}$ & Min GD & Max GD & $\begin{array}{c}\text { Mean GD to } \\
\text { others }\end{array}$ & $\begin{array}{l}\text { SD to } \\
\text { others }\end{array}$ & $\begin{array}{c}\text { Min GD to } \\
\text { others }\end{array}$ & $\begin{array}{c}\text { Max GD to } \\
\text { others }\end{array}$ \\
\hline Cluster I & 4.06 & 0.72 & 3.65 & 4.57 & 2.37 & 5.37 & 5.74 & 1.30 & 3.06 & 10.0 \\
\hline Cluster II & 4.72 & 0.72 & 4.41 & 5.39 & 2.72 & 6.72 & 5.61 & 1.10 & 2.84 & 9.5 \\
\hline Cluster III & 4.28 & 0.71 & 4.16 & 4.40 & 3.43 & 5.29 & 5.74 & 1.30 & 3.09 & 9.4 \\
\hline Cluster IV & 4.15 & 0.91 & 3.40 & 5.20 & 2.04 & 7.25 & 5.36 & 1.26 & 2.88 & 10.5 \\
\hline Cluster V & 4.27 & 0.84 & 3.53 & 5.26 & 2.17 & 6.7 & 5.1 & 1.18 & 2.81 & 10.1 \\
\hline Cluster VI & 3.69 & 0.28 & 3.52 & 3.83 & 3.40 & 4.0 & 5.73 & 1.25 & 3.12 & 10.7 \\
\hline Cluster VII & 4.39 & 0.94 & 3.70 & 4.91 & 2.3 & 6.76 & 5.94 & 1.38 & 2.8 & 11.0 \\
\hline Cluster VIII & 5.12 & 0.72 & 4.71 & 5.38 & 4.21 & 6.38 & 6.17 & 1.10 & 3.79 & 9.5 \\
\hline Cluster IX & 4.97 & 1.11 & 4.40 & 6.13 & 3.23 & 7.9 & 6.19 & 1.29 & 3.08 & 11.0 \\
\hline Cluster X & 5.73 & 1.17 & 4.97 & 6.15 & 4.89 & 7.2 & 6.49 & 1.31 & 3.09 & 10.4 \\
\hline Cluster XI & & & & & & & 7.67 & 1.15 & 5.19 & 10.0 \\
\hline Cluster XII & 5.85 & 0.93 & 5.59 & 6.20 & 5.2 & 7.9 & 7.89 & 1.37 & 4.42 & 11.0 \\
\hline
\end{tabular}

Min and Max GD represented minimum and maximum genetic distances measured from 17 agro-morphology and physicochemical traits of 116 sweet potato accessions grouped under different clusters. SD=standard deviation.

The means of 12 clusters for 17 agro-morphology and physicochemical traits are presented in Table 7 . The four clusters characterized with highest means for 2 to 7 traits without having low means for any other traits. Of which Cluster XI had highest mean for vine length, above ground fresh and dry biomass yield, average number of storage roots per plant, unmarketable storage root yield ton per hectare, total sugar content and total starch content in percent. Whereas Cluster XII had highest means for storage root fresh weight, total storage root yield ton per hectare and marketable storage root yield ton per hectare. Cluster I and VII each for two traits recorded the highest means of which the former cluster for days to physiological maturity and reducing sugar content and the later for $\mathrm{pH}$ and total soluble solids. Opposite to this, four clusters had lowest mean values for 1 to 6 traits. Among these, the two clusters, Cluster VI and Cluster VII, each for six traits had lowest means. For Cluster VI, these were for storage-root fresh weight, average mass of storage root gram per plant, total storage root yield ton per hectare, marketable storage root yield ton per hectare, dry matter content in percent and total soluble solids. Cluster VII for days to physiological maturity, vine length, average number of storage roots per plant, unmarketable storage-root yield ton per hectare, total sugar and total starch content. In addition, Cluster IV for above ground fresh and dry biomass yield and Cluster IX for reducing sugar content had lowest mean values.

Table 7: Means of 12 cluster groups of 116 sweet potato accessions for 17 agro-morphology and physicochemical traits

\begin{tabular}{|c|c|c|c|c|c|c|c|c|c|c|c|c|}
\hline Trait & C-I & C-II & C-III & C-IV & C-V & C-VI & C-VII & C-VIII & C-IX & $C-X$ & C-XI & C-XII \\
\hline DTPM & 184.16 & 167.09 & 168.34 & 170.04 & 162.28 & 178.18 & 149.68 & 175.22 & 172.84 & 182.01 & 159.342 & 179.72 \\
\hline NBP & 8.40 & 8.66 & 5.70 & 8.47 & 8.90 & 6.78 & 5.99 & 7.57 & 6.95 & 14.28 & 9.447 & 6.95 \\
\hline $\mathrm{VL}(\mathrm{cm})$ & 59.91 & 77.37 & 65.17 & 58.51 & 72.35 & 74.70 & 38.42 & 92.86 & 88.64 & 89.65 & 94.862 & 53.05 \\
\hline $\operatorname{SRFW}(\mathrm{g})$ & 511.02 & 335.88 & 306.99 & 281.31 & 289.11 & 130.34 & 187.55 & 468.62 & 218.14 & 381.59 & 530.65 & 777.67 \\
\hline AGFB & 1441.36 & 1697.50 & 1915.00 & 930.56 & 2160.91 & 1471.67 & 1788.33 & 1562.50 & 3456.67 & 1945.00 & 5060 & 1902.50 \\
\hline AGDB & 821.45 & 840.71 & 637.50 & 594.17 & 1159.39 & 1097.00 & 787.50 & 775.00 & 1648.33 & 756.67 & 1690 & 747.50 \\
\hline ANSR/p & 8.09 & 5.79 & 8.00 & 7.39 & 5.73 & 6.33 & 5.08 & 6.50 & 6.33 & 6.33 & 10 & 5.25 \\
\hline AMSR/p & 149.91 & 135.86 & 93.00 & 102.11 & 122.55 & 68.00 & 184.67 & 168.00 & 212.44 & 134.67 & 268 & 193.00 \\
\hline TSRYt ha ${ }^{-1}$ & 17.03 & 11.19 & 10.26 & 9.38 & 9.64 & 3.96 & 6.15 & 15.62 & 7.19 & 12.71 & 17.661 & 25.91 \\
\hline MSRYt ha ${ }^{-1}$ & 10.83 & 7.15 & 5.87 & 6.23 & 6.11 & 1.72 & 5.11 & 8.80 & 4.75 & 11.58 & 9.112 & 18.82 \\
\hline USRYt ha-1 & 6.21 & 4.05 & 4.36 & 3.15 & 3.52 & 2.62 & 1.14 & 6.82 & 2.52 & 1.14 & 8.576 & 7.10 \\
\hline DMC (\%) & 27.43 & 25.07 & 36.65 & 23.55 & 21.22 & 17.84 & 20.59 & 26.39 & 23.76 & 27.88 & 23.445 & 26.94 \\
\hline RS & 7.75 & 6.20 & 6.25 & 6.45 & 5.83 & 5.93 & 5.01 & 5.67 & 4.93 & 6.55 & 5.231 & 7.51 \\
\hline TS & 14.17 & 15.87 & 13.61 & 11.67 & 13.26 & 14.90 & 11.19 & 13.89 & 11.88 & 12.30 & 17.248 & 14.24 \\
\hline TSC (\%) & 13.46 & 15.08 & 12.93 & 11.09 & 12.59 & 14.16 & 10.63 & 13.20 & 11.29 & 11.69 & 16.392 & 13.36 \\
\hline $\mathrm{pH}$ & 6.13 & 6.11 & 6.37 & 6.16 & 6.23 & 5.82 & 6.29 & 6.83 & 6.22 & 5.66 & 6.349 & 6.18 \\
\hline TSS & 11.13 & 11.63 & 12.13 & 11.47 & 13.34 & 11.05 & 13.84 & 14.69 & 12.22 & 13.05 & 12.632 & 11.07 \\
\hline
\end{tabular}

C-I to CXII represented cluster I to XII. DTPM= days to physiological maturity, NBP= number of branches per plant, VL (cm)= vine length in centimeter, $\mathrm{SRFW}(\mathrm{g})=$ storage root fresh weight gram per plant, $\mathrm{AGFB}=$ above ground fresh biomass yield gram per plant, $A G D B=$ above ground dry biomass gram per plant, $A N S R / p=$ average number of storage roots per plant, AMSR/p= average mass of storage root gram per plant, TSRY $t$ ha ${ }^{-1}=$ total storage root

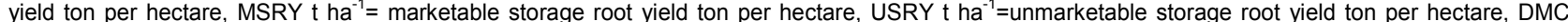
$(\%)=$ dry matter content in percent, RS $=$ reducing sugar content, TS $=$ total sugar content, TSC $(\%)=$ total starch content in percent and TSS $=$ total soluble solids.

The two clusters, III and $\mathrm{X}$, had highest mean values for dry matter content and number of branches per plant but low for number of branches per plant and $\mathrm{pH}$, respectively. The other two Clusters, II and V, had neither high nor low means for any of the traits. However, all the cluster II members had higher total sugar and starch contents than overall mean of accessions but all had lower means for $\mathrm{pH}$ and total soluble solids. In this cluster,
Subgroup I characterized by consisting accessions with higher days to physiological maturity and except one accession all members of the sub-group had higher mean values greater than the overall mean of accessions for storage root fresh weight, above ground dry biomass and total storage root yield ton per hectare. The other Subgroup II contained all accessions introduced from Asian and all had higher mean for number of branches per plant, 


\section{Wassu Mohammed et al.,}

dry matter content, days to physiological maturity and total soluble solids, but lower mean than the overall mean of accessions for above ground fresh and dry biomass and $\mathrm{pH}$. Cluster $\mathrm{V}$ consisted of accessions which had a wide range of values for most of the traits and sub-divided the cluster in to five sub-groups. Generally, the cluster had higher mean values than overall mean of accessions for number of branches per plant, vine length, above ground fresh and dry biomass, total sugar and starch content, $\mathrm{pH}$ and total soluble solids, but lower means for all other traits. However, 7-22 and 11-16 accessions had lower and higher mean values than overall means of accessions for the traits, which the cluster had higher and lower means than the overall means of accessions, respectively.

\section{DISCUSSION}

The presence of variations among 116 sweet potato accession was observed from analysis of variance and a wide range of mean performance of accessions. Though non-significant differences among accessions were observed for 4 out of 17 traits, the extent of variations ranged from 70.57 to $87.36 \%$. Variations among and within different groups (Asia, Cuba, Nigeria, local collections and improved varieties) were evident from all data analyses. Each group of accessions exhibited highest and lowest mean values for different traits. Individual accessions from different groups outsmarted the improved varieties for all traits. The presence of variation is critical for selection of cultivars. Therefore, the presence of sufficient variability among sweet potato accessions will allow selection to be effected. Knowledge of genetic variability in crop improvement is the most sustainable method to conserve valuable genetic resources for the future, and simultaneously to increase agricultural production and food security (Haussmann et al., 2004). More importantly, the observed variations among local collections showed the importance of collecting, evaluating and maintaining genetic resources for improvement of sweet potato productivity and other desirable traits. This is in agreement with other authors who reported high genetic diversity among the sweet potato germplasm in East African region with the majority being farmers' varieties existing under different names (Yada et al., 2010; Abdelhameed et al., 2007; Abidin, 2004; Gichuki et al., 2003; Bashasha et al., 1995; Kapinga et al., 1995).

Genotypic coefficient of variation values were les than 10 for 11 out of 17 traits and only for 4 and 2 traits the values were ranged from 10.28 to $14.59 \%$ and $>20 \%$, respectively. On the contrary, phenotypic coefficient of variation values were $<20 \%$ for seven traits while it was $>20$ up to $55.38 \%$ for 10 traits. This indicated that the genotypic coefficient of variation values were low for most of the traits while phenotypic coefficient of variation values were moderate and high for majority of traits as proposed by Sivasubramanian and Menon (1973). In addition, the estimated phenotypic coefficient of variation was greater than the genotypic coefficient of variation in magnitude for all the traits and the differences were moderate to high. The observed moderate to high differences between phenotypic and genotypic coefficient of variations noticed for most of the traits further indicating higher sensitivity of these traits to environmental modifications which might be difficult to improve traits through selection of high performing accessions.
Sci. Technol. Arts Res. J., Jan-March 2015, 4(1): 09-19

Heritability in broad sense was $32.02 \%$ for reducing sugar, 89.06 and $97.64 \%$ for days to physiological maturity and $\mathrm{pH}$, respectively. Heritability in percentage for all other traits (14 out of 17 traits) was $<30 \%$. Genetic advance as per cent mean was $<10 \%$ for all traits except $11.24,16.29$ and $42.21 \%$ for average number of storage roots per plant, unmarketable storage root yield $\left(\mathrm{t} \mathrm{ha}^{-1}\right.$ ) and $\mathrm{pH}$, respectively. As proposed by Robinson et al. (1949) and Johnson et al. (1955), heritability and genetic advance were moderate to high only for the traits with $>30$ and $10 \%$ heritability and genetic advance, respectively. Moreover, only both heritability and genetic advance values were moderate to high for average number of storage roots per plant, unmarketable storage root yield $(t$ $\mathrm{ha}^{-1}$ ) and $\mathrm{pH}$ that showed an indication of more additive gene action (Panse, 1957) and selection is effective to improve these traits. However, selection of high performing genotypes for unmarketable storage root yield $\left(\mathrm{t} \mathrm{ha}{ }^{-1}\right.$ ) and $\mathrm{pH}$ will not be the breeding objective sweet potato. For most of the traits, which both heritability and expected genetic advance values were low, indicated that selection might be considerably difficult to improve the crop due to the masking effect of environment on the genotypic effect (Chahal and Gosal, 2010).

Wide range of genetic distances (2.04-11) was observed between pairs of accessions. Near to equal proportion of 15.14 and $15.35 \%$ pairs of accessions were most distant (>7.04) and closest (<4.3), respectively. The two improved varieties were close each other with minimum distance. Among and between groups of accessions pairs, 18.06, 16.58, 16.38 and $15.72 \%$ of Nigeria to Asia (1872), Nigeria to local (900), Local to Asia (1300) and Nigeria to Nigeria (630), respectively, were the most distant. Whereas 48.08, 28, 25, 24 and $21.15 \%$ of Barkume to Asia (52), Barkume to Local (25), Barkume to Nigeria (36), Local to Local (300), Adu to Asia (52) and Local to Cuba (25), respectively, were the most closest pairs. The minimum distance between the improved varieties is expected because the varieties were selected for same desirable agro-morphology traits. Most distant pairs of accessions were obtained both within and between groups of accession, but most closest were between improved variety Barkume and accessions from different groups. The largest distances among accessions is likely accounted for by the presence of different content accessions and the diverse accessions collected within the content. Pairs of the within accessions from African and these accessions with other content accessions were more distant.

The pairs of between accessions from Africa and accessions with other contents being the most distant might showed that Africa is a center of diversity for sweet potato. Certain areas of the world exhibit high level of genetic variability for crops and considered as center of genetic diversity (Eivazi et al., 2007). High genetic diversity has been observed among the sweet potato germplasm in East African region and the region is considered as secondary center of diversity (Yada et al., 2010; Abdelhameed et al., 2007, Gichuki et al., 2003). The current result also showed the need to continue genetic variability study of the crop in the country and continent. Because, genetic diversity study exposes the genetic variability in diverse populations and it is a major breakthrough in understanding intraspecies crop performance leading to crop improvement (Mostafa et al., 2011, Aremu, 2005). 
Wassu Mohammed et al.,

The Unweighted Pair-group Method with Arithmetic means (UPGMA) efficiently grouped (12 clusters) accessions with some similarity in to same cluster with no overlapping of accessions. This showed that UPGMA method was efficient in grouping accessions. Cluster analysis have five methods of which UPGMA and UPAMC provide more accurate grouping information on breeding materials than the other clusters (Aremu et al., 2007a). The clusters and accessions in each cluster had distinct traits that can be used in breeding programme. For instance, Cluster I and XII contained accessions that produced high storage root yield, where as Cluster III and $X$ had highest means for dry matter content and number of branches per plant. The first step of any meaningful breeding programme is to identify crop plants that exhibit exploitable variation for the trait(s) of interest. In this regard, the current study was efficient in generating information about the extent of genetic divergence of accessions that can serve as a platform for specific breeding objectives. Genetic diversity study is necessary to understand the genetic relationships among populations and to assign accessions to specific heterogeneous groups that help to identify parental lines for best combinations with maximum genetic potential for further selection (Mostafa et al., 2011; Aremu et al, 2007b, Thompson et al., 1998).

The two improved varieties (checks) with lowest distance were grouped in the first cluster. Accessions obtained from Asia, Nigeria and Ethiopia (local collections) were distributed in all clusters except the former in one, the second and third in three clusters. However, 61.54, 69.44 and $68 \%$ of the accessions from Asia, Nigeria and Ethiopia (local collections), respectively, were grouped under three different clusters. Highest distances of 11 and 10.9 were exhibited for pairs of accessions from Nigeria and Local and Local and Local, respectively. The lowest distances of $2.04,2.27$ and 2.3 were computed between pairs of accessions from Nigeria, Asia and Local and Asia accessions, respectively. The result showed that accessions stood out in any of dendrogram regardless of accessions sources with some genetic similarity. The most distant and closest accessions observed within the same and/or different germplasm sources indicating both the geographic areas of collection and genetic makeup of the accessions were important for diversity. However, the tendency of accessions to be close each other obtained from the same geographic area or with one of the geographic area indicating the germplasm source had important effect for diversity. More importantly, accessions from Africa (Nigeria and Local collections) were more distant each other and with accessions from other geographic areas with desirable traits (storage root yield and others). This indicates sweet potato accessions from African were more diverse than accessions from other contents, and this can be used for improvement of the crop.

Plant breeders require genetically diverse materials to develop improved crop varieties. The more diverse the gene pool, the higher is the probability that it would contain desirable genes to improve the crop (De Silva et al., 1995). The result also showed that the importance of collection and characterization of sweet potato germplasm in the country to conserve for future requirements by eliminating duplicates (Huaman, 1992). These accessions have wide and diverse origin and genetic background known as genetic diversity which helps to understand
Sci. Technol. Arts Res. J., Jan-March 2015, 4(1): 09-19

intraspecies crop performance leading to crop improvement (Aremu, 2005). Genetic diversity of crops is possible to be revealed from the existing variations in the nature of individual or group of individual crop accessions using specific statistical method or combination of methods (Aremu, 2005; Warburton and Crossa 2000). The identified variations are expected to form a pattern of genetic relationship useable in grouping accessions. In grouping of accessions, cluster analysis has ability to identify crop accessions with highest level of similarity using the dendrogram (Aliyu et al., 2000).

The increased population in developing nations in the world has gradually led to food shortage and increased poverty. Addressing and tackling the problem is one major challenge to breeders ( $\mathrm{Fu}$ and Somers, 2009). Crop improvement techniques therefore remain a major concern to plant breeders (Aremu et al., 2007a, Akbar and Kamran, 2006). Several factors affect crop improvement but more importantly crop genotype (Aremu, et al., 2007b). Germplasm is, therefore, an essential resource for successful plant breeding. This is because the crop genotypes have wide and diverse origin and genetic background known as genetic diversity that allows selection of accessions for the improvement of the crop. Genetic diversity in crop may be associated with the origin of the crop or origin and geographical diversity may not be important in genetic diversity (Aremu et al., 2007a; Nair et al., 1995). In this regard, the current study revealed a wide genetic diversity in sweet potato accessions obtained from the same or different regions (contents). This indicated the importance of both geographical locations and genetic makeup of individual accessions. This was evident from the large proportions of pairs of local collections both among themselves and with introduced accessions being the most distant.

More importantly, the local collections performed better than higher performing improved variety (check) for all traits with minimum of two for storage fresh root weight and total storage root yield $\mathrm{t} \mathrm{ha}^{-1}$ and a maximum of 22 local collections for aboveground fresh biomass. This showed the possibility of selection of accessions for the trait(s) of interest to improve the crop from local collections as equal to introduced accessions. The availability of genetic variability among population is most important for judicious selection and breeding to desired plant genotypes (Singh et al., 2006). If crop origin is somewhat not important in the measure of genetic diversity, a resource centre is therefore needed to preserve and maintain the wide genetic sources exploitable in breeding programmes (Brown, 1995).

\section{CONCLUSIONS}

The improvement of crops is a function of genetically diverse materials where the presence of more diverse materials ensures the higher probability of containing desirable genes to improve the crop. Therefore, the first step in the improvement of crops is either to create variation or to study the extent of variation and diversity in existing crop germplasm. The present study results showed the presence of appreciable variation among accessions for all the characters studied. Wide genetic diversity was observed in 116 sweet potato accessions that were clustered in 12 big groups where each group was distinct. More importantly, large proportions of pairs of local collections both among themselves and with introduced accessions being the most distant and 


\section{Wassu Mohammed et al.,}

performed better than higher performing improved variety (check) with a minimum of two and at most 22 collections in each trait. This showed the importance of collecting, evaluating and maintaining of local genetic resources for the improvement of sweet potato productivity in the country. The study revealed the higher possibility of obtaining accessions better than the existing commercial varieties for all traits through selection that will allow breeders to improve the crop in the region in particular and in the country at large. The study also showed that sweet potato accessions maintained by Haramaya University are the most distant/diverse which need further maintaining of the materials for future improvement of the crop.

\section{Conflict of Interest}

The authors declared no conflict of interest

\section{Acknowledgments}

The authors are grateful to the financial support of Haramaya University and Ethiopian Ministry of Education for the execution of the research. The authors also thank the staff members of Horticulture Program, School of Plant Sciences of Haramaya University for their technical assistance during the time of conducting the experiment at both the field and laboratory.

\section{REFERENCES}

Abdelhameed, E., Fjellheim, S., Larsen, A., Rognli, O.A., Sundheim, L., Msolla, S., Masumba, E., and Mtunda, K. (2007). Analysis of genetic diversity in sweet potato (Ipomoea batatas L. Lam) germplasm collection from Tanzania as revealed by AFLP. Genetic Resources and Crop Evolution 55 (3): 397-408.

Abhishek, R., Parsad, R. and Gupta, V.K. (2010). Statistical package for augmented design (SPAD). New delhi: IASRI, Library Avenue.

Abidin, P.E. (2004). Sweet potato breeding for north eastern Uganda: Farmer varieties, farmer participatory selection and stability performance. PhD Dissertation, Wageningen University, the Netherlands.

Adhanom, N., Tsedeke, A. and Emana, G. (1985). Research on insect pests of roots and tuber crops. In: Tsedeke Abate (ed.) (1985). A Review of Crop Protection Research in Ethiopia: Proceedings of the first Ethiopian Crop Protection Symposium, 4-7 February,1985, Institute of Agricultural Research, Addis Ababa, Ethiopia.

Akbar, A.A. and Kamran, M. (2006). Relationship among yield components and selection criteria for yield improvement of Safflower-Carthamustinctorious L. Journal of Applied Sciences 6: 2853-2855.

Aliyu, B. and Fawole, N.G.N.Q. (2000). Inheritance of Pubescence in crosses between Vigna unguiculata and V. rhomboidea. Nigeria Journal of Genetics 15: 9-14.

Allard, R.W. (1960). Principles of Plant Breeding. New York: John Willy and Sons, Inc.

Aremu, C.O. (2005). Diversity selection and genotypes environment interaction in cowpea. $\mathrm{PhD}$ Dissertation, Abeokuta University of Agriculture, Nigeria.

Aremu, C.O., Adebayo, M.A., Ariyo, O.J. and Adewale, B.D. (2007b). Classification of genetic diversity and choice of parents for hybridization in cowpea [Vigna unguiculata (L.) Walip] for humid savanna ecology. African Journal of Biotechnology 6: (20) 2333-2339.
Sci. Technol. Arts Res. J., Jan-March 2015, 4(1): 09-19

Aremu, C.O., Adebayo, M.A., Oyegunle, M. and Ariyo, J.O. (2007a). The relative discriminatory abilities measuring genotype by environment interaction in soybean (Glycine max). Agricultural Journal 2 (2): 210-215.

Bashasha, B.R.O.M., Mwanga, C., Ocittip, O. and Ewell, P.T.(1995). Sweet potato in the farming and food system of Uganda: A farm survey report. CIP Sub-Saharan Africa Region, National Agricultural Research Organization, Nairobi, Kenya.

Brown, A.H.D. (1995). The core collection at the crossroads. In: Hodgkin T, Brown AHD, van Hintum TJL and Morales EAV (eds) Core Collections of Plant Genetic Resources. Rome, IPGRI, John Wiley and Sons, Sayce Publishing, pp. 3-19.

Burton, G.A. and Devane, E.H. (1953). Estimation of heritability in tall festca (Festuca arundinacea) from replicated clonal materials. Agronomy Journal 45:478479.

Caldo, R.A., Sebastian, L.S. and Hernandez, J.E. (1996). Morphology based genetic diversity analysis of ancestral lines of Rice in Philippine rice cultivars. Philippines Journal of Crop Science 21(3):86-92.

Chahal, G.S. and Gosal, S.S. (2010). Principles and Procedures of Plant Breeding: Biotechnology and Conventional Approaches. New Delhi, Chennai, Mumbai and Kolkata, Narosa Publishing House.

CSA (Central Statistical Authority). (2011). Ethiopian agricultural sample enumeration. Statistical bulletin, 146, Addis Abeba, Ethiopia.

De Silva, K.P.U. and Premathilake, A. (1995). Screening of sweet potato genotypes in rice fallow environments. Incorporation of users' criteria in variety development of sweet potato. Selected research papers 1994/95. Sweet Potato 1-7.

Eivazi, A.R., Naghavi, M.R., Hajheidari, M., Mohammadi, S.A., Majidi, S.A., Salakdeh, I. and Mardi, M. (2007). Assessing wheat genetic diversity using quality traits, amplified fragment length polymorphism simple sequence repeats and proteome analysis. Annual Applied Biology 152:81-91.

Endale, T., Geleta, L., Mulugeta, D. and Terefe, B. (1992). Improvement studies on Ensete and Sweet potato. pp. 63-74. In: Horticultural Research and Development in Ethiopia. Proceeding of second National Horticulture Workshop of Ethiopia, 13 December, 1992. Addis Ababa, Ethiopia.

Falconer, D.S. (1990). Introduction to Quantitative Genetics $\left(3^{\text {rd }}\right.$ ed.). New York, John Wiley and Sons, Inc.

FAO (1989). Plant genetic resources: Their conservation in situ for human use. FAO, Rome, Italy.

FAO (2006). World information and early warning system on plant genetic resources. Food and Agriculture Organization of the United Nations, Rome.

FAOSTAT (2012). Global production and consumption of root and tuber. In FAO corporate document repository. Report on the Inter-center review of root and tuber crops research in the CGIAR. [Available online: http://www.fao.org.; Accessed in June15, 2013].

Fu, Y. and Somers, D. (2009). Genomo-wide reduction of genetic diversity in wheat breeding. Crop Science 49:161168.

Gibson, R.W. and Aritua, V. (2002). The perspective of Sweet potato: Chrolotic stunt virus in Sweet potato production in 


\section{Wassu Mohammed et al.,}

Africa: A review. African Crop Science Journal 10(4): 281 -310 .

Gichuki, S.T., Barenyi, M., Zhang, D., Hermann, M., Schmidt, J., Glossl, J. and Burg, K. (2003). Genetic diversity in sweet potato [Ipomoea batatas (L.) Lam.] in relationship to geographic sources as assessed with RAPD markers. Genetic Resources and Crop Evolution 50: 429-437.

Haussmann, B. I. G., Parzies, H. K., Prester, T., Sus, Z. and Miedaner, T. (2004). Plant genetic resources in crop improvement. Plant Genetic Resources 2(1): 3-21.

Huaman, Z. (1992). Morphologic identification of duplicates in collections of Ipomoea batatas. CIP Research Guide 36. Lima, Peru: International Potato Center. p. 28.

IPGRI (International Plant Genetic Resources Institute). (1991). Descriptors of sweet potato, Rome, Italy. pp 2556.

Johnson, H.W., Robinson, H.F. and Comstock, R.E. (1955). Estimates of genetic and environmental variability in soybeans. Agronomy Journal 47: 314-318.

Kapinga, R.E., Ewell, P.T., Jeremiah, S.C. and Kileo, R. (1995). Sweet potato in Tanzania farming and food systems: Implications for research, CIP, Sub-saharan Africa Region, Nairobi, Kenya/Ministry of Agriculture, Dares Salaam, Tanzania. pp.47.

Mazumdar, B.C. and Mazumdar, K. (2003). Method of Physicochemical Analysis of Fruits. New Delhi, India, Daya publishing house.

MoARD (Ministry of Agriculture and Rural Development). (2007). Crop variety register. Crop development department, No. 10, pp. 126-129, Addis Abeba, Ethiopia.

Mostafa, K., Mohammad, H. and Mohammad, M. (2011). Genetic diversity of wheat genotype based on cluster and principal component analyses for breeding strategies. Australian Journal of Crop Science 5 (1): 17-24.

Nair, G.M. and Nair, R.B. (1995). Influence of irrigation and fertilizer on the growth attributes of sweet potato. Journal of Root Crops 21. 17-23.

O' Brien, P.J. (1972). The Sweet potato: its origin and dispersal. American Anthropology 74: 343-365.

Panse, U.G. (1957). Genetics of quantitative characters in relation to plant breeding. Indian Journal of Genetics 17: 318-328.

Purohit, S.R. and Mishra, B.K. (2012). Simultaneous scarification and fermentation of overnight soaked Sweet
Sci. Technol. Arts Res. J., Jan-March 2015, 4(1): 09-19 potato for Ethyl alcohol fermentation. Advance Journal of Food Science and Technology 4(2): 56-59.

Robinson, H.F., Comstock, R.E. and Harvery, V.H. (1949). Estimates of heritability and degree of dominance in corn. Agronomy Journal 41: 353-359.

Sigmund, R. and Gustav, E. (1991). The Cultivated Plants of Tropics and Sub-tropics: Cultivation, economic value, utilization. CTA, verlag Josef margrave, Germany.

Simret, B. (2010). Influence of inorganic nitrogen and potassium fertilizers on seed tuber yield and size distribution of potato (Solanum tuberosum L.). MSc. Thesis, Haramaya University, Ethiopia.

Singh, B., Pal, A. K. and Singh, S. (2006). Genetic variability and correlation analysis in Okra. Indian Journal of Horticulture 63 (3): 281-285.

Sivasubramanian, S. and Menon, M. (1973). Heterosis and inbreeding depression in rice. Madras Agriculture Journal 60: 1139.

Sneath, P.H.A. and Sokal, R.R. (1973). Numerical Taxonomy. CTA, Freeman, San Francisco, America.

Thompson, J.A., Nelson, R.L. and Vodkin, L.O. (1998). Identification of diverse soybean germplasm using RAPD markers. Crop Science 38: 1348-1355.

Warburton, M. and Crossa, J. (2000). Data analysis in the CIMMYT. Applied biotechnology center for fingerprinting and genetic diversity studies. CIMMYT, Mexico.

Yada, B.P., Tukamuhabwa, B., Wajala, D.J., Kim, R.A., Skilton, A., Alajo and Mwanga, R. (2010). Characterizing Ugandan sweet potato germplasm using fluorescent labeled simple sequence repeat markers. Horticulture Science 45(2):225-230.

Zhang, D., Rossel, G., Kriegner, A. and Hijman, R. (2004). AFLP assessment of diversity in Sweet potato from Latin America and the Pacific region: Its implications on the dispersal of the crop. Genetic Resource and Crop Evolution 51: 115-120.

Zhang, D.P., Carbajulca, D., Ojeda, L., Rossel, G., Milla, S., Herrera, C. and Ghislain, M. ( 2000). Microsatellite analysis of genetic diversity in Sweet potato varieties from Latin America. CIP Program Report, 1999 -2000. pp 295301.

Zihin, Y., Ozlem, T. and Gulsum, O. (2011). Determination of sweet potatoes [Ipomoea batatas (L.) Lam.] genotypes suitable to the Aegean region of Turkey. Turkish Journal of Field Crops 16(1): 48-53 